\title{
Design and testing of a pilot-scale submerged membrane bioreactor (MBR) for textile wastewater treatment
}

\author{
Shamim Ahmed Deowan ${ }^{1,6}$ (Dladimir Korejba ${ }^{1} \cdot$ Jan Hoinkis $^{1} \cdot$ Alberto Figoli $^{2} \cdot$ Enrico Drioli $^{3} \cdot$ Rafiqul Islam $^{4}$. \\ Lafia Jamal ${ }^{5}$
}

Received: 8 May 2017 / Accepted: 15 March 2019 / Published online: 27 March 2019

(c) The Author(s) 2019

\begin{abstract}
The objective of this paper is to deal with the design of a pilot-scale submerged membrane bioreactor (MBR) and a shortterm functionality test to be performed with textile wastewater. The design calculations were done based on the design parameters analysed from local textile wastewater and typical values of activated sludge kinetic coefficients. Other process parameters like bioreactor volume (tank size), hydraulic residence time (HRT), biomass loading ( $F / M$ ratio), oxygen demand, etc., were calculated depending on the real textile wastewater characteristics. Taking the design basis into consideration, a pilot-scale MBR was constructed equipped with LabVIEW programme- and sensors-controlled computer system. Based on the theoretical calculations, the hydraulic volume of the MBR reactor was around $56.6 \mathrm{~L}$ with flat sheet membranes $(3$ sheets, with $25 \mathrm{~cm} \times 25 \mathrm{~cm}$ dimensions of each sheet) with HRT of $16.9 \mathrm{~h}$. Finally, performance tests for 6 weeks were carried out in a local (Darmstadt, Germany) laundry textile wastewater to test the functionality of MBR pilot plant. Under the operating conditions of 250 mbar suction pressure and $12 \mathrm{~g} / \mathrm{L}$ of MLSS, the COD removal efficiency was around $90 \%$ for 800-3500 $\mathrm{mg} / \mathrm{L}$ inlet COD fed to the membrane bioreactor.
\end{abstract}

Keywords MBR $\cdot$ Design $\cdot$ Wastewater $\cdot$ Test $\cdot$ Reuse

Shamim Ahmed Deowan

sadeowan@gmail.com

Alberto Figoli

a.figoli@itm.cnr.it

Enrico Drioli

e.drioli@unical.it

Rafiqul Islam

professorrafiqulislam@yahoo.co.uk

Lafia Jamal

lafifa@du.ac.bd

1 Karlsruhe University of Applied Sciences, Moltkestr. 30, 76133 Karlsruhe, Germany

2 Institute on Membrane Technology, ITM-CNR, Via P. Bucci, cubo 17/C, 87030 Rende, Italy

3 University of Calabria, 87030 Rende, CS, Italy

4 Department of Applied Chemistry and Chemical Engineering, University of Dhaka, Dhaka 1000, Bangladesh

5 Department of Robotics and Mechatronics Engineering, University of Dhaka, Dhaka 1000, Bangladesh

6 Present Address: Department of Robotics and Mechatronics Engineering, University of Dhaka, Dhaka 1000, Bangladesh

\section{Introduction}

Membrane bioreactor (MBR) technology is a combination of the conventional biological sludge process, a wastewater treatment process characterized by a suspended growth of biomass, with a micro- or ultrafiltration membrane system (Judd 2006, p. 55). The biological unit is responsible for the biodegradation of the waste compounds and the membrane module for the physical separation of the treated water from the mixed liquor. The pore diameter of the membranes is in the range between 0.01 and $0.1 \mu \mathrm{m}$ so that particulates and bacteria can be kept out of permeate and the membrane system replaces the traditional gravity sedimentation unit (clarifier) in the biological sludge process. Hence, the MBR offers the advantage of higher product water quality and low footprint. Due to its advantages, membrane bioreactor technology has great potential in wide ranging applications including municipal and industrial wastewater treatment (e.g. textile) and process water recycling.

Wastewater reclamation and reuse are effective tools for sustainable industrial development programmes. Increasingly stringent environmental legislation and generally 
enhanced intensity, efficiency and diversity of treatment technologies have made the reuse of water more viable in many industrial processes. Membrane bioreactors (MBRs) technology will be an essential part of advancing such water sustainability because they encourage water reuse and open up opportunities for decentralized treatment. Moreover, membrane bioreactor (MBR) technology is recognized as a promising technology to provide water with reliable quality for reuse and is very attractive for industrial, e.g. textile wastewater treatment (Brik et al. 2006). But the performance of MBR technology depends on the proper design of the plant considering different factors required for optimum outcome (Yang et al. 2006). This paper deals with the design of a pilot-scale MBR to obtain optimum performance of this kind of technology, and the trial was done for 6 weeks using textile wastewater. The optimum design of the technology can prove the viability of the technology and open up a door of a reliable technology for industrial wastewater treatment and reuse.

\section{Materials and methods}

The works carried out throughout this paper were divided into two sections as mentioned below:

Table 1 Textile wastewater quality

\begin{tabular}{lll}
\hline Parameter & Unit & Value \\
\hline Inlet COD & $\mathrm{mg} / \mathrm{L}$ & 3200 \\
Soluble COD (sCOD) & $\mathrm{mg} / \mathrm{L}$ & 2336 \\
BOD & $\mathrm{mg} / \mathrm{L}$ & 650 \\
Soluble BOD (sBOD) & $\mathrm{mg} / \mathrm{L}$ & 474 \\
Total suspended solids (TSS) & $\mathrm{mg} / \mathrm{L}$ & 400 \\
Volatile suspended solids (VSS) & $\mathrm{mg} / \mathrm{L}$ & 240 \\
TKN & $\mathrm{mg} / \mathrm{L}$ & 40 \\
pH & & $7-9$ \\
Temperature & ${ }^{\circ} \mathrm{C}$ & 20 \\
Electrical conductivity & $\mu \mathrm{S} / \mathrm{cm}$ & 1900 \\
AOX & $\mathrm{mg} / \mathrm{L}$ & 0.06 \\
MLSS & $\mathrm{g} / \mathrm{L}$ & 12 \\
Cu & $\mathrm{mg} / \mathrm{L}$ & 5 \\
\hline
\end{tabular}

- Design and construction of a pilot-scale MBR plant

- Performance tests of the developed pilot-scale MBR plant

\section{Design and construction of a pilot-scale MBR plant}

\section{Wastewater quality}

Some design parameters were calculated based on the wastewater quality (Table 1) of a local laundry textile wastewater. It was considered that the constructed MBR plant was supposed be tested in the same textile industry after its development.

\section{Design conditions and assumptions}

The design of the MBR plant was done based on the following conditions and assumptions:

(a) Mechanical aerator with oxygen transfer efficiency, $\mathrm{O}_{2, \text { eff. }}=28 \%$

(b) Liquid depth for aeration basin $=54 \mathrm{~cm}$

(c) Dissolved oxygen (DO) in the aeration basin $=3 \mathrm{mg} / \mathrm{L}$ (normal range of DO is $2-4 \mathrm{mg} / \mathrm{L}$; for better functionality of microorganisms, the $\mathrm{DO}$ of $3 \mathrm{mg} / \mathrm{L}$ has been assumed)

(d) Site (Karlsruhe, Germany) elevation above sea level $=115 \mathrm{~m}$

(e) Oxygen transfer correction factor, $\alpha=0.6$

(f) Salinity-surface tension correction factor, $\beta=0.95$

(g) Fouling factor $F$, which accounts for membrane fouling $=0.77$

(h) Activated sludge kinetic coefficients are given in Table 2.

(i) Sludge retention time (SRT) $=12$ days

(j) Design MLSS $=12 \mathrm{~g} / \mathrm{L}$

(k) Ratio of VSS to TSS (VSS/TSS) $=0.601$

\section{Design parameters}

The design parameters shown in Table 3 were considered for design calculations. Some of the parameters were obtained by the analysis of the effluent (permeate), while others were determined using applicable equations.
Table 2 Activated sludge kinetic coefficients (Eswaramoorthi et al. 2008)

\begin{tabular}{lllll}
\hline Parameter & Coefficient & Unit & Range & Typical value \\
\hline Endogenous decay coefficient & $K_{\mathrm{d}}$ & $\mathrm{g}$ VSS/g VSS day & $0.06-0.2$ & 0.12 \\
$\begin{array}{l}\text { Fraction of cell mass remaining as cell debris } \\
\text { Biomass yield, mass of cell formed per mass }\end{array}$ & $f_{\mathrm{d}}$ & unit less & $0.08-0.2$ & 0.15 \\
$\quad$ & & $\mathrm{~g}$ VSS/g bCOD & $0.3-0.5$ & 0.4 \\
$\begin{array}{l}\text { Half substrate consumed } \\
\text { Maximum specific growth rate }\end{array}$ & $K_{\mathrm{s}}$ & $\mathrm{mg} \mathrm{bCOD} / \mathrm{L}$ & $5.0-40.0$ & 20 \\
& $\mu_{\mathrm{m}}$ & $\mathrm{g}$ VSS/g VSS day & $3.0-13.2$ & 6 \\
\hline
\end{tabular}


Table 3 Design parameters

\begin{tabular}{|c|c|c|c|c|}
\hline Parameter & Notation & Unit & Value & Comment \\
\hline Soluble COD & sCOD & $\mathrm{mg} / \mathrm{L}$ & 2336 & Analysed by effluent \\
\hline Soluble BOD & sBOD & $\mathrm{mg} / \mathrm{L}$ & 474 & Analysed by effluent \\
\hline Influent wastewater TSS concentration & TSS & $\mathrm{mg} / \mathrm{L}$ & 400 & Analysed by influent wastewater \\
\hline Influent wastewater VSS concentration & VSS & $\mathrm{mg} / \mathrm{L}$ & 240 & Calculated based on VSS/TSS ratio \\
\hline Influent of wastewater & $Q$ & L/day & 80 & Measured \\
\hline Solid retention time & SRT & $\mathrm{D}$ & 12 & Measured \\
\hline Mixed liquor suspended solid & MLSS & $\mathrm{g} / \mathrm{L}$ & 12 & Analysed \\
\hline Biodegradable COD & $\mathrm{bCOD}$ & $\mathrm{mg} / \mathrm{L}$ & 1200 & $\begin{array}{l}\text { Calculated based on bCOD/BOD ratio } \\
\text { (Eswaramoorthi et al. 2008) }\end{array}$ \\
\hline Non-biodegradable COD & nbCOD & $\mathrm{mg} / \mathrm{L}$ & 2160 & Calculated \\
\hline Effluent soluble COD & sCODe & $\mathrm{mg} / \mathrm{L}$ & 1576.6 & Calculated \\
\hline Non-biodegradable VSS & nbVSS & $\mathrm{mg} / \mathrm{L}$ & 162 & Calculated \\
\hline Endogenous decay coefficient & $K_{\mathrm{d}}$ & g VSS/g VSS day & 0.12 & Typical value used \\
\hline Fraction of cell mass remaining as cell debris & $f_{\mathrm{d}}$ & unit less & 0.15 & Typical value used \\
\hline $\begin{array}{l}\text { Biomass yield, mass of cell formed per mass of substrate } \\
\text { consumed }\end{array}$ & $Y$ & $\mathrm{~g}$ VSS/g bCOD & 0.4 & Typical value used \\
\hline Half-velocity constant & $K_{\mathrm{s}}$ & $\mathrm{mg} \mathrm{bCOD/L}$ & 20 & Typical value used \\
\hline Maximum specific growth rate & $\mu_{\mathrm{m}}$ & g VSS/g VSS day & 6 & Typical value used \\
\hline Biomass as VSS wasted per day & $P_{X, \text { bio }}$ & g/day & 19.1 & Calculated \\
\hline Effluent substrate concentration & $S$ & $\mathrm{mg} \mathrm{bCOD/L}$ & 0.702 & Calculated \\
\hline Cylindrical volume of the reactor & $V_{\text {cyl }}$. & $\mathrm{L}$ & 51.9 & Calculated \\
\hline Conical volume of the reactor & $V_{\text {con. }}$ & $\mathrm{L}$ & 4.8 & Calculated \\
\hline Aeration tank volume & $V$ & $\mathrm{~L}$ & 56.7 & Adding $V_{\text {cyl. }}$ and $V_{\text {con. }}$ \\
\hline Hydraulic residence time & HRT & $\mathrm{H}$ & $\sim 17$ & Calculated \\
\hline Mixed liquor volatile suspended solid & MLVSS & $\mathrm{g} / \mathrm{L}$ & 6.65 & Calculated \\
\hline Food-to-biomass ratio & $F / M$ & & 0.38 & Calculated \\
\hline Observed yield based on TSS & $Y_{\text {obs,TSS }}$ & g TSS/g BOD & 0.37 & Calculated \\
\hline Observed yield based on VSS & $Y_{\text {obs,VSS }}$ & g VSS/g BOD & 0.22 & Calculated \\
\hline Oxygen demand & $m_{\mathrm{O}}$ & $\mathrm{g} / \mathrm{h}$ & 0.65 & Calculated \\
\hline Air flow rate needed to transfer the required oxygen & $V_{\text {air }}$ & $\mathrm{m} 3 / \mathrm{h}$ & 0.03 & Calculated \\
\hline $\begin{array}{l}\text { Net waste activated sludge produced each day, measured in } \\
\text { terms of total suspended solids }\end{array}$ & $P_{X, \mathrm{TSS}}$ & g/day & 56.6 & Calculated \\
\hline Equivalent to bCOD & $S_{\mathrm{O}}$ & $\mathrm{mg} / \mathrm{L}$ & 1200 & Calculated \\
\hline $\begin{array}{l}\text { Oxygen saturation concentration in clean water at tempera- } \\
\text { ture } \mathrm{T} \text { and altitude } \mathrm{H}\end{array}$ & $C_{S, T, H}$ & $\mathrm{mg} / \mathrm{L}$ & 8.94 & $\begin{array}{l}\text { Calculated at } 20^{\circ} \mathrm{C} \text { and at altitude of } \\
\text { Karlsruhe }(115 \mathrm{~m} \text { above sea level })\end{array}$ \\
\hline Operating oxygen concentration & $C_{L}$ & $\mathrm{mg} / \mathrm{L}$ & 3 & Assumed from typical value of $(2-4 \mathrm{mg} / \mathrm{L})$ \\
\hline $\begin{array}{l}\text { Dissolved oxygen saturation concentration in clean water at } \\
20^{\circ} \mathrm{C} \text { and } 1 \mathrm{~atm}\end{array}$ & $C_{S, 20}$ & $\mathrm{mg} / \mathrm{L}$ & 9.02 & Calculated (US EPA 1989) \\
\hline Temperature & $T$ & ${ }^{\circ} \mathrm{C}$ & 20 & Assumed \\
\hline Standard oxygen transfer rate & SOTR & $\mathrm{g} / \mathrm{h}$ & 2.3 & Calculated \\
\hline Density of air in Karlsruhe (above $115 \mathrm{~m}$ of sea level) & $\rho_{\text {air }}$ & $\mathrm{kg} / \mathrm{m}^{3}$ & 1.188 & Calculated \\
\hline Oxygen concentration in air & $\mathrm{O}_{2, \text { conc. }}$ & $(\%)$ & 21 & Assumed \\
\hline Air flow rate needed to supply the required oxygen rate & $V_{\text {air }}$ & $\mathrm{m}^{3} / \mathrm{h}$ & 0.033 & Calculated \\
\hline
\end{tabular}

\section{Design of MBR reactor (aeration tank)}

Determination of reactor (aeration tank) volume The volume of the reactor was calculated from Eq. 1 (Eswaramoorthi et al. 2008):

$V=\left(P_{X, \mathrm{TSS}} * \mathrm{SRT}\right) / X_{\mathrm{TSS}}$, where $P_{X, \mathrm{TSS}}$ is the net waste activated sludge produced each day, measured in terms of total suspended solids, $X_{\mathrm{TSS}}$ is equivalent to MLSS, and $V$ is the volume which needs to be calculated.

$P_{X, \text { TSS }}$ was calculated using Eq. (2):

$P_{X, \mathrm{TSS}}=P_{X, \mathrm{bio}, \mathrm{VSS}}+Q \mathrm{nbVSS}+Q(\mathrm{TSS}-\mathrm{VSS})$. 
Since VSS/TSS $=0.601$, the Eq. 2 can be rewritten as (Eswaramoorthi et al. 2008):

$P_{X, \mathrm{TSS}}=P_{X, \mathrm{bio}} / 0.601+Q \mathrm{nbVSS}+Q(\mathrm{TSS}-\mathrm{VSS})$.

The value of $P_{X, \text { TSS }}$ depends on $P_{X \text {,bio }}$ which can be calculated using Eq. (4):

$P_{X, \text { bio }}=\frac{Q Y\left(S_{\mathrm{O}}-S\right)}{1+K_{\mathrm{d}} * \mathrm{SRT}}+\frac{f_{\mathrm{d}} K_{\mathrm{d}} Q Y\left(S_{\mathrm{O}}-S\right) * \mathrm{SRT}}{1+K_{\mathrm{d}} * \mathrm{SRT}}$.

Effluent substrate concentration $(S)$ is calculated using Eq. (5):

$S=\frac{K_{\mathrm{s}}\left(1+K_{\mathrm{d}} * \mathrm{SRT}\right)}{\operatorname{SRT}\left(\mu_{\mathrm{m}}-K_{\mathrm{d}}\right)-1}$.

Calculating the values of $S, P_{X \text {,bio }}, P_{X \text {,Tss }}$ from Eqs. (5), (4) and (3), respectively, and putting them in Eq. (1), the volume of reactor was calculated. The correspondent values are presented in Table 3.

Determination of aeration tank size From Eq. (1), the calculated reactor volume was $56.6 \mathrm{~L}$. To ease the availability of the tank size, commercially available plastic tank with diameter of $35 \mathrm{~cm}$ was selected. The tank had conical shape which was used as excess sludge disposal exit area. The cylindrical volume, $V_{\text {cyl }}$, calculated using Eq. (6) was in line with the expected volume:

$V_{\text {cyl. }}=\pi R^{2} L$

where $R$ is the radius of the tank $(17.5 \mathrm{~cm})$ and $L$ is the vertical length. The conical volume $V_{\text {con. }}$ (Alexander and Koeberlein 2014) of the reactor was calculated from Eq. (7):

$V_{\text {con. }}=\frac{1}{3} B H$,

where

$B=\pi R^{2}$

and $H$ is the height (the perpendicular distance from the base to the apex).

Considering $H=15 \mathrm{~cm}$, the conical volume was found around $4.8 \mathrm{~L}$. The length of the available cylindrical tank was $66 \mathrm{~cm}$. Taking $L=54 \mathrm{~cm}$, cylindrical volume from Eq. (6) was found around 51.9 L. The summation of cylindrical volume and conical volume resulted in total volume of the reactor which was equal to $56.7 \mathrm{~L}$ (closed to the calculated volume). Figure 1 outlines the MBR reactor size.

Calculation of hydraulic residence time (HRT) Hydraulic residence time (HRT) was calculated based on Eq. (9):

$\mathrm{HRT}=\frac{V}{Q}$, where $V$ is the volume of the reactor and $Q$ is the permeate flow. In this case, permeate flow and feed flow were equal since hydraulic level in the reactor was maintained constant by level sensor. The value of HRT is given in Table 3 .

Determination of oxygen demand Oxygen demand was calculated applying Eq. (10) (Metcalf and Eddy 2003):

$m_{\mathrm{O}}=Q\left(S_{\mathrm{O}}-S\right)-1.42 P_{X, \text { bio }}+4.33 Q\left(\mathrm{NO}_{X}\right)-2.83 Q\left(\mathrm{NO}_{X}\right)$,

where $S_{\mathrm{O}}$ is equivalent to COD. The first term in Eq. (10) refers to substrate oxidation, the second refers to biomass respiration, the third refers to nitrification, and the final term refers to denitrification (Judd 2006). Without considering nitrification and/or denitrification, the Eq. (10) can be written as

$m_{\mathrm{O}}=Q\left(S_{\mathrm{O}}-S\right)-1.42 P_{X, \text { bio }}$.

The calculated value of $m_{\mathrm{O}}$ is given in Table 3 .

Calculation of standard oxygen transfer rate (SOTR) For the calculation of standard oxygen transfer rate (SOTR), Eq. (12) is used (Metcalf and Eddy 2003):

$\operatorname{AOTR}=\operatorname{SOTR}\left(\frac{\beta C_{\bar{S}, T, H}-C_{L}}{C_{S, 20}}\right) \times\left(1.024^{T-20}\right)(\alpha)(F)$,

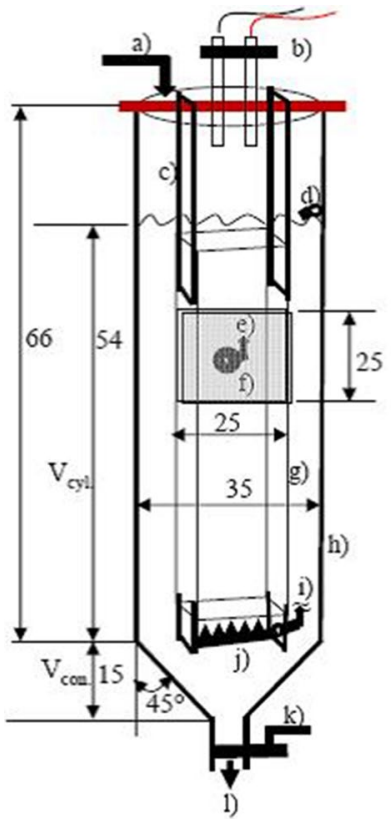

Notations:

a) Feed

b) Foam sensor

c) Membrane module holder

d) Level sensor

e) Permeate suction channel

f) Membrane module

g) Membrane module casin

h) MBR reactor (aeration tank)

i) Air supply channel

j) Mechanical aerator

k) Disposal valve

1) Excess sludge disposal system

$\mathrm{V}_{\mathrm{cyl}}$ : Cylindrical volume

$\mathrm{V}_{\text {cou. }}$ : Conical volume

N.B. All dimensions are in $\mathrm{cm}$

Fig. 1 MBR reactor 
where AOTR $=$ actual oxygen transfer rate $(\mathrm{g} / \mathrm{h})$ equivalent to $m_{\mathrm{O}} ; \mathrm{SOTR}=$ standard oxygen transfer rate $(\mathrm{g} / \mathrm{h})$.

The terms in Eq. 12 are given in Table 3.

For surface aerator $C_{\bar{S}, T, H}=C_{S, T, H}$.

Therefore,

$$
\text { SOTR }=\frac{\text { AOTR }}{\left(\frac{\beta C_{S, T, H}-C_{L}}{C_{S, 20}}\right)\left(1.024^{T-20}\right)(\alpha)(F)} .
$$

The calculated value of SOTR is given in Table 3 .

Calculation of air flow rate needed to meet the required SOTR The air flow rate needed to meet the required SOTR was calculated using Eq. (14):

$\rho_{\text {air }}=\frac{M_{\text {air }}}{V_{\text {air }}}$,

where $V_{\text {air }}$ is the volume of air and $M_{\text {air }}$ is the mass of air which is related to SOTR as it can be correlated as shown in Eq. (15):

SOTR $=M_{\text {air }} * O_{2 \text {,conc. }} * O_{2 \text {,eff. }}$.

To calculate the required air, Eq. (14) is rewritten as follows:

$V_{\text {air }}=\frac{\text { SOTR }}{\left(O_{2, \text { conc. }} * O_{2, \text { eff. }} * \rho_{\text {air }}\right)}$.

The calculated value of $V_{\text {air }}$ is given in Table 3 .

\section{Construction and implementation of MBR pilot plant}

Since around $60 \%$ of the operation cost of MBR technology comes from the air supply which is needed for microorganisms for their functionality, the main objective of this paper was to design and calculate how much air is needed for the MBR operation which can be shown by Eq. 16 along with other design parameters. The suction pressure or transmembrane pressure is an associated parameter which is normally in the range of around 500 mbar and requires less energy, that's why suction pressure has been excluded in the model.

Construction of MBR reactor Selecting the MBR reactor size as shown in Fig. 1, the flat sheet membrane module (UF membrane, PES, pore size $0.050 \mu \mathrm{m}$, dimensions $25 \mathrm{~cm} \times 25 \mathrm{~cm}$ ) from company Microdyn-Nadir, Germany, was installed inside the reactor. The module consists of three flat sheets membrane each of having $0.11 \mathrm{~m}^{2}$ of area giving total area of $0.33 \mathrm{~m}^{2}$. The membrane module was equipped with mechanical aerator at the bottom of the module and permeate suction channel in the middle of the module casin. Air was supplied by a compressor. To avoid any movement of the module, it was fixed with the head of the
MBR reactor with the help of module holder. It was taken care that the module was always submerged in the hydraulic volume ensured by level sensor. The permeate suction channel of the module was connected to a differential pressure sensor to measure the transmembrane pressure (TMP), and it was followed by a vacuum pump which created permeate flow. Feed was supplied by a feed pump. A foam sensor was incorporated at the top of the reactor to abate excess foam. Some other sensors were installed to ascertain $\mathrm{pH}$, conductivity, temperature of feed and permeate. All the process parameters were monitored, and data were stored by LabVIEW programme-controlled computer system.

\section{Experiment}

\section{Start-up of the MBR pilot plant}

To check the functionality of the installed membrane bioreactor, some trials were done with water following the operation conditions as mentioned in Table 4. Firstly, the MBR plant was started with DI water for $1.5 \mathrm{~h}$. All the equipment and instruments were checked if they were functioning properly.

After the first trial, the plant was tested with tap water of Karlsruhe (Germany) for almost $1.5 \mathrm{~h}$ and functionality of the plant was checked in the similar way. The results of the DI water test and tap water tests are shown in Fig. 2.

\section{Field tests of the developed pilot-scale MBR plant}

After running several trials of MBR with DI water and tap water with reproducible results, the plant was tested for 6 weeks with real laundry textile wastewater from where the data of water quality were the basis of MBR design. During this trial period, the industry was using different types of washing agents. So, MBR trial faced the variation of wastewater qualities and tests were carried out in different cycles.

Full duration of trials (6 weeks) was covered by 11 operating cycles depending on the wastewater quality of

Table 4 Experimental operating conditions

\begin{tabular}{llll}
\hline Process parameters & \multicolumn{2}{l}{ Laboratory trial } & \multirow{2}{*}{ Field trial } \\
\cline { 2 - 3 } & DI water & Tap water & \\
\hline Transmembrane pressure (mbar) & 50 & 160 & 200 \\
Temperature $\left({ }^{\circ} \mathrm{C}\right)$ & $20 \pm 1$ & $22 \pm 1$ & $25 \pm 1$ \\
$\mathrm{pH}$ & $6.5 \pm 0.2$ & $7.0 \pm 0.5$ & $6.5 \pm 0.5$ \\
Operation time $(\mathrm{h} / \mathrm{weeks})$ & $1.5 \mathrm{~h}$ & $1.5 \mathrm{~h}$ & 6 weeks \\
Conductivity $(\mu \mathrm{S} / \mathrm{cm})$ & $100 \pm 5$ & $460 \pm 5$ & $1200 \pm 5$ \\
$\mathrm{COD}(\mathrm{mg} / \mathrm{L})$ & - & - & $800-3500$ \\
\hline
\end{tabular}


Flux effect with suction pressure

(DI water, pH: $6,5 \pm 0,2$, temp.: $20 \pm 1^{\circ} \mathrm{C}$, Cond.: $100 \pm 5$

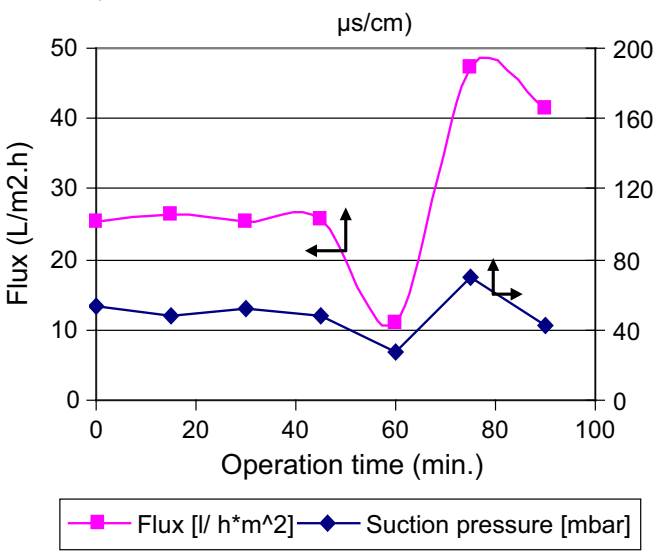

(a)

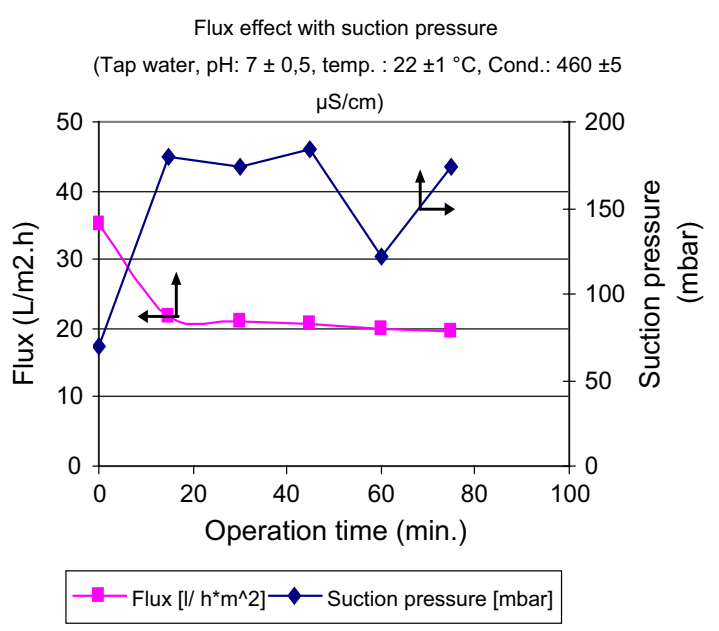

(b)

Fig. 2 Start-up results of MBR with a DI water and $\mathbf{b}$ tap water

different processes. To judge the test performance of the trials, some process parameters of one operation cycle and COD removal efficiency are shown in Figs. 3 and 4, respectively.

\section{Results and discussion}

From Fig. 2, it is noticed that the fluxes of the start-up were 25 and $20 \mathrm{~L} / \mathrm{m}^{2} \mathrm{~h}$ with 50 and 160 mbar of TMPs using DI water and tap water, respectively. Design of the pure water flux of this membrane is supposed to be $15-25 \mathrm{~L} / \mathrm{m}^{2} \mathrm{~h}$ with the operating TMP range of 40-400 mbar provided by membrane provider (Microdyn-Nadir 2010). So, the start-up results were in line with the expected results. From Fig. 3, it is noticed that the permeate flux is around $9 \mathrm{~L} / \mathrm{m}^{2} \mathrm{~h}$ with TMP of 200 mbar and the COD removal efficiency was around $90 \%$ as indicated in Fig. 4 for $800-3500 \mathrm{mg} / \mathrm{L}$ inlet COD fed to the membrane bioreactor. In conventional activated sludge (CAS) system, COD removal efficiency is around $50-60 \%$ since it only works by microorganisms in aerobic conditions. In MBR system, physical separation of permeate also happens along with biological degradation in aerobic conditions which increases the efficiency of the overall wastewater treatment system. That's why high COD removal efficiency was observed in the applied MBR system along with expected flux production. Even higher performance could be achieved if it continues for longer time
Fig. 3 Process parameters of pilot MBR
Flux effect with suction pressure (Textile wastewater, $\mathrm{pH}: 6.5 \pm 0.5$, temp. : $25 \pm 1$, cond. : $1200 \pm 5 \mu \mathrm{s} / \mathrm{cm}$ )

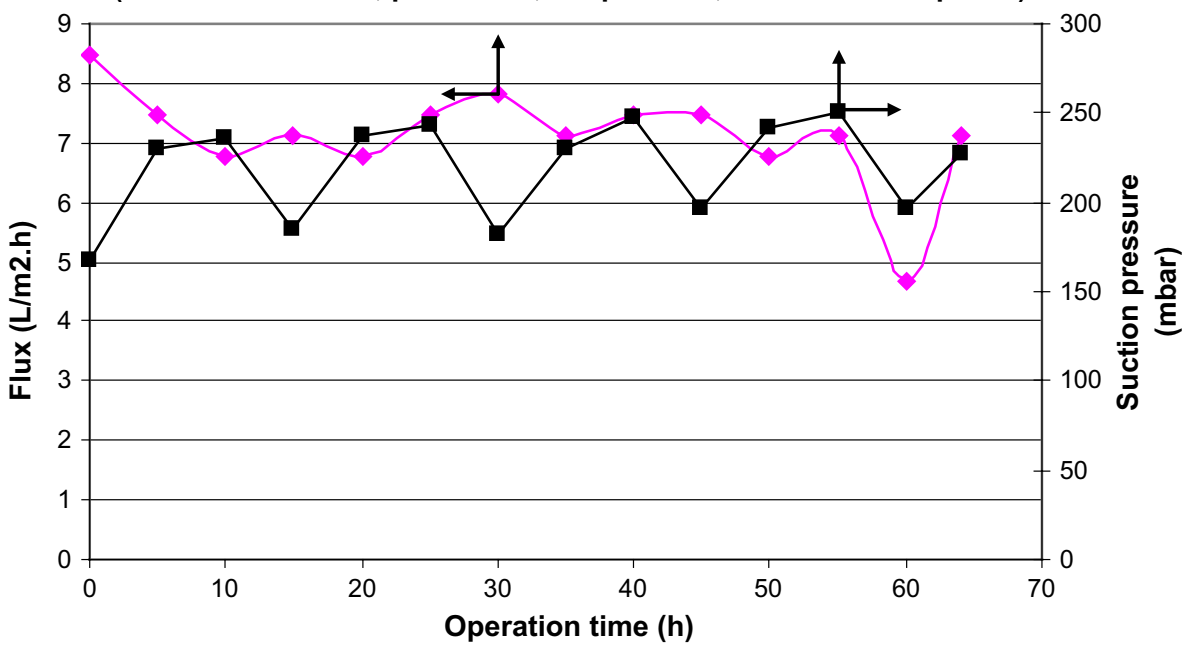

-Flux (L/m2.h) $\rightarrow-$ Suction pressure (mbar) 
Fig. 4 COD removal efficiency of pilot MBR

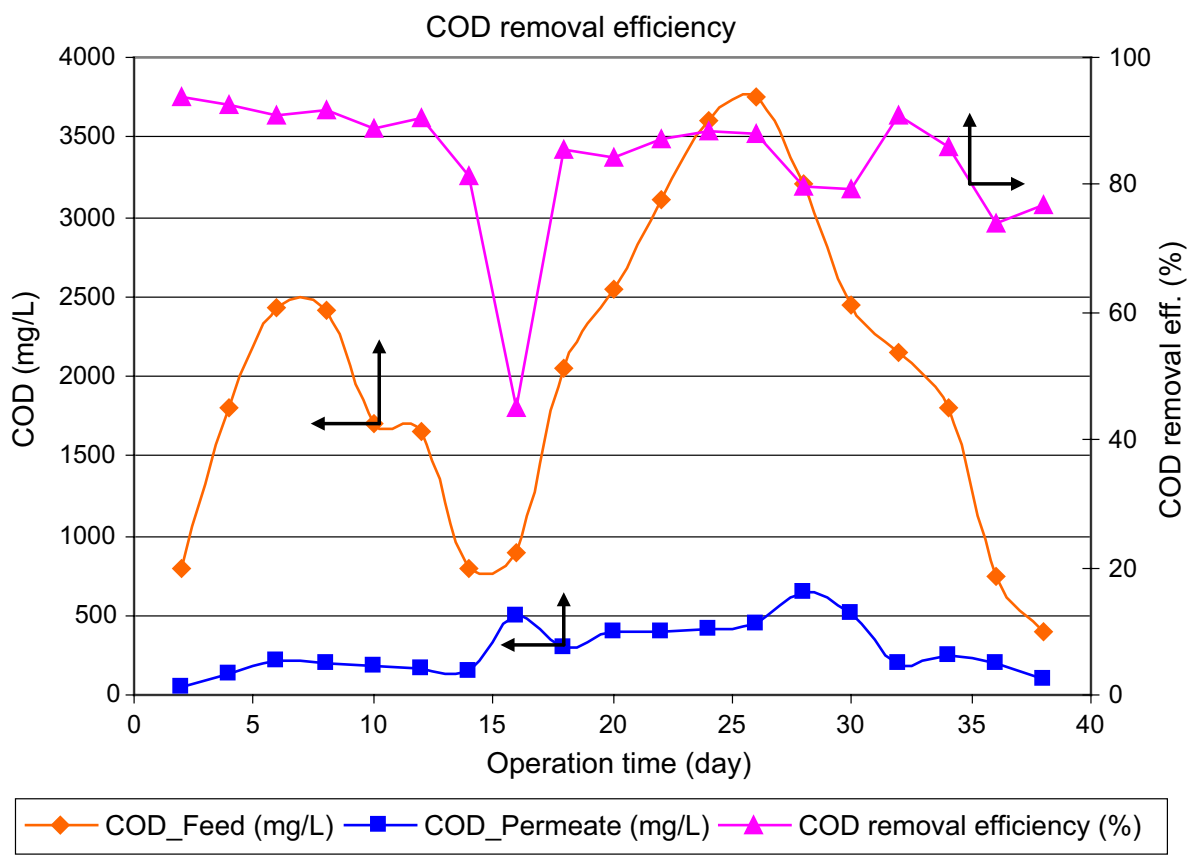

so that the microorganism can be adapted further with the system. This high-level COD removal efficiency opens up an option to recycle the permeate as process water in the industry.

\section{Conclusion}

The start-up experiment with pure water/tap water and the field trial with real textile wastewater show very good results with around 90\% COD removal efficiency. The HRT and other parameters of the trials were well fitted to the design conditions. The applied aeration rate was $1.0 \mathrm{~m}^{3} / \mathrm{h}$ which was quite high compared to the designed aeration rate. But this aeration was also used to create cross-flow beside the oxygen transfer. Generally, it can be concluded that the testing results indicate more or less perfection of the design for pilot-scale MBR plant. This MBR plant is recommended to test with textile wastewater for several months investigating flux, TMP, COD, MLSS, $F / M$ ratio, etc., for further verification of the design.

Acknowledgements The authors would like to acknowledge and thank Institute of Applied Research (IAF), Karlsruhe University of Applied Sciences, Germany, for financial and technical support. The authors also thank Mr. Volker Panten and Mr. Klingelmeyer of TextilService Klingelmeyer GmbH \& Co KG, Darmstadt, Germany, for their cooperation.

Open Access This article is distributed under the terms of the Creative Commons Attribution 4.0 International License (http://creativeco mmons.org/licenses/by/4.0/), which permits unrestricted use, distribution, and reproduction in any medium, provided you give appropriate credit to the original author(s) and the source, provide a link to the Creative Commons license, and indicate if changes were made.

\section{References}

Alexander DC, Koeberlein GM (2014) Elementary geometry for college students. Cengage Learning, Boston. ISBN 978-1-285-19569-8

Brik M, Schoeberl P, Chamam B, Braun R, Fuchs W (2006) Advanced treatment of textile wastewater towards reuse using a membrane bioreactor. Process Biochem 41:1751-1757

Eswaramoorthi S, Dhanapal K, Chuahan DS (2008) Application of membrane bioreactor for textile wastewater treatment: pilot plant process modelling and scale-up. Environment With People's Involvement \& Co-ordination in India, Coimbatore, India

Judd S (2006) The MBR book: principles and applications of membrane bioreactors in water and wastewater treatment. Elsevier, Amsterdam

Metcalf and Eddy (2003) Wastewater engineering: treatment and reuse, 4th edn. McGraw-Hill, New York. ISBN 0-07-112250-8

Microdyn-Nadir (2010) MBR operating manual. Microdyn-Nadir $\mathrm{GmbH}$, Wiesbaden, Germany

US EPA (1989) Design manual—fine pore aeration systems. Center for Environmental Research, Cincinnati

Yang W, Cicek N, Ilg J (2006) State-of-the-art of membrane bioreactors: worldwide research and commercial applications in North America. J Membr Sci 270(1-2):201-211

Publisher's Note Springer Nature remains neutral with regard to jurisdictional claims in published maps and institutional affiliations. 